\title{
Evaluation of Heavy Metal Phytoextraction Potential of Rhizophora Racemosa in Niger Delta Mangrove Forest, Rivers State, Nigeria
}

\author{
*Gbosidom, V. L* Nyodee, G. T Ngerebara, N. N \\ Department of Science Laboratory Technology, Kenule Beeson Saro-Wiwa Polytechnic, \\ Bori, Rivers State, Nigeria
}

\begin{abstract}
The bio transfer and bio translocation factors of heavy metals in the tissues of Rhizophora racemose was evaluated in this study. Soil, roots and shoot samples of the study plant were randomly collected from Kono, Bomu, Ogu and Borokiri mangrove forests at wet and dry seasons, digested and analyzed for heavy metals using standard laboratory methods. The laboratory results of field samples were further subjected to bio transfer and bio translocation factors analysis. Findings on wet season bio transfer factor revealed the concentrations of $\mathrm{Cr}$ $(0.36 \mathrm{mg} / \mathrm{kg}), \mathrm{Ni}(0.86 \mathrm{mg} / \mathrm{kg}), \mathrm{Cd}(2.86 \mathrm{mg} / \mathrm{kg}), \mathrm{Pb}(1.17 \mathrm{mg} / \mathrm{kg})$ and $\mathrm{Zn}(1.85 \mathrm{mg} / \mathrm{kg})$, while dry season showed $\mathrm{Cr}(0.36 \mathrm{mg} / \mathrm{kg}), \mathrm{Ni}(0.55 \mathrm{mg} / \mathrm{kg}), \mathrm{Cd}(1.24 \mathrm{mg} / \mathrm{kg}), \mathrm{Pb}(2.72 \mathrm{mg} / \mathrm{kg})$ and $\mathrm{Zn}(1.99 \mathrm{mg} / \mathrm{kg})$. The bio translocation factor results for wet season indicated the concentrations of $\mathrm{Cr}(0.51 \mathrm{mg} / \mathrm{kg}), \mathrm{Ni}(1.47 \mathrm{mg} / \mathrm{kg}), \mathrm{Cd}(1.02 \mathrm{mg} / \mathrm{kg})$, $\mathrm{Pb}(1.48 \mathrm{mg} / \mathrm{kg})$ and $\mathrm{Zn}(0.88 \mathrm{mg} / \mathrm{kg})$, while dry season result revealed $\mathrm{Cr}(0.41 \mathrm{mg} / \mathrm{kg}), \mathrm{Ni}(0.65 \mathrm{mg} / \mathrm{kg}), \mathrm{Cd}$ $(1.24 \mathrm{mg} / \mathrm{kg}), \mathrm{Pb}(1.50 \mathrm{mg} / \mathrm{kg})$ and $\mathrm{Zn}(0.81 \mathrm{mg} / \mathrm{kg})$. This study therefore classifies Rhizophora racemose as a hyper accumulator of $\mathrm{Pb}$ and $\mathrm{Cd}$ in shoot tissues and non-hyper accumulator of $\mathrm{Cr}, \mathrm{Ni}$ and $\mathrm{Zn}$ in root tissues. Beside other uses, the plant has shown high affinity for the accumulation of heavy metals and thus can be used for phytoremediation.
\end{abstract}

Keywords: Phytoextraction, mangrove, heavy metals, evaluation, bio-transfer, bio-translocation

DOI: $10.7176 / J N S R / 12-14-03$

Publication date:July $31^{\text {st }} 2021$

\section{Introduction}

The Niger Delta region has over the years been prone to various forms of pollution, some of which are due to inundation by oil spills. Oil spillage in the region had been attributed to pipeline corrosion, leakages from well heads, poor maintenance of oil related infrastructures, human errors, oil theft and vandalization (Adeola, 2000; Amnesty International 2009).

The pollution of this coastal belt is further aggravated by poor regulation of oil related activities such as exploration and exploitation of crude oil and gas(Erakrumen, 2007). The Niger Delta mangrove swamp forest had been reported as highly productive for fisheries resources (Akankali and Jamabo, 2012). This mangrove forest falls among locations that are exposed to large deposits of wastes and pollutants due to the innate characteristics of growing in environments with tidal fluctuation (Erakrumen, 2014). Studies have shown that about 35\% of endangered red and threatened species are either located or depend on wetland habitats and fish species require the estuaries either as nursery ground or for their entire lives' subsistence (Sulton and Shun, 1996).

Information on heavy metals pollution is necessitated as it is currently a problem needing global attention (Marchand et al, 2006), consequent on the premise that they are non-biodegradable and their persistence and accumulation in the environment causes toxicity in organisms (Ghosh and Singh 2005, Neff et al., 2006).

The sources of heavy metals are both natural and anthropogenic while natural sources contribute lesser proportion, anthropogenic sources contribute greater percentage. These sources include but not limited to mining and smelting, industrial waste, pipeline vandalization, domestic waste, fertilizers, pesticides, sewage sludge. and oil spill. The 2004 World congress on environmental health observed that metal poisoning of the environment is becoming a major public health problem in African Countries due to industrialization and globalization (Carnie, 2004).

In a bid to revegetate highly contaminated sites by heavy metals, metal tolerant plant species are cultivated to cushion the effect of migration of contaminants by soil leaching, contamination of ground water, wind and transportation of exposed soil surfaces (Stoltz and Greger, 2002; Tordoff et al, 2000). These plants possess the characteristics that enable them to absorb metals by their roots and translocate them to shoot organs where they are accumulated at higher concentrations (Baryla et al,2001).

Therefore, this study examines the potential of Rhizophora racemose for phytoextraction of heavy metals.

\section{Methodology}

The methodology adopted for this work is presented the subsections below. 


\subsection{Study Area}

$\mathrm{T}$ The study area for this research stretches from longitude $7^{0} 05^{\prime} 00^{\prime} \mathrm{E}$ through longitude $7^{0} 30^{\prime} 30^{\prime \prime} \mathrm{E}$ and latitude $4^{0} 45^{\prime} 30^{\prime \prime} \mathrm{N}$ in Rivers State. Four stations in mangrove forests were chosen in four local Government Areas namely Kono (station 1) in Khana local government area, Bomu (station 2) in Gokana local government area, Ogu (station 3) in Ogu/gbolo local government area and Borokiri (station 4) in Port Harcourt City local government area, were enlisted and used for the study.

\subsection{Sampling}

The randomized complete block design (RCBD) was used in sampling. Wet season sampling was undertaken in the months of July and August, 2017, while dry season samples were collected in the months of January and February 2018. Soil samples were randomly collected at $0-30 \mathrm{~cm}$ in three replications at the rhizosphere of study plant growth site using soil auger, and stored in clean cellophane bags. Plant samples (roots, leaf and stem) were randomly collected in three replicates each and stored in clean cellophane bags. All samples were labelled with appropriate sample identities, Samples were protected from external contaminants and were transported to the laboratory in plastic cooler containers for heavy metals analysis.

\subsection{Laboratory Analysis}

Plant samples were prepared by drying them to constant weight in hot air oven using model T5028 at $1500 \mathrm{c}$. After drying, samples were pulverized into fine powder using mortar and pestle, while ensuring noncontamination. Pulverized samples were then sieved to enhance dissolution in solution during analysis.

Samples were digested by weighing $2 \mathrm{~g}$ of each into respective $250 \mathrm{ml}$ beakers. To each beaker containing samples $132 \mathrm{ml}$ of deionized water was added. Subsequently, 5ml HN03, 10ml H2SO4 and 2ml H2O2 were added and made up to $150 \mathrm{ml}$ using deionized water.

The respective solutions were heated using heating apparatus in a fume cupboard till the volumes were reduced to about $50 \mathrm{ml}$. The digested samples were allowed to cool after which they were filtered using cotton wool into $100 \mathrm{ml}$ volumetric flask and made up to $100 \mathrm{ml}$ by washing with deionized water. Samples were stored in pre-labeled sample bottles for heavy metal analysis.

Soil samples were dried at 1000c in a hot air oven (model T5028) to constant weight. Samples were then crushed, homogenized and sieved using skitter. Digestion was done following the method described by Eduardo et al, (2005). $1 \mathrm{~g}$ of each sample was dissolved in $5 \mathrm{ml} \mathrm{HNO3} \mathrm{(70 \%} \mathrm{v/v),} \mathrm{5ml} \mathrm{HCL04} \mathrm{(70 \%} \mathrm{v/v)} \mathrm{and} \mathrm{10ml}$ $\mathrm{HF}(48 \% \mathrm{v} / \mathrm{v})$. The resultant solution was heated in a mantle (model MY6403) to dryness. The residue was allowed to cool, then dissolved in $5 \mathrm{ml} \mathrm{HCL}(36 \% \mathrm{v} / \mathrm{v})$ and $20 \mathrm{ml}$ deionized water. It was then filtered and washed through cotton wool into respective pre-labeled $100 \mathrm{ml}$ volumetric flasks, and made up to $100 \mathrm{ml}$.

The concentrations of heavy metals in plant and soil samples were determined using Perkin -Elmer 200 Atomic Absorption spectrophotometer (AAS) in conformity with the described method by Perkin- Elmer corporation, (1996).

\subsection{Determination of Bio Transfer Factor (BTF) and Bio Translocation Factor (BTLF)}

The The bio transfer factor (BTF) of heavy metals was evaluated according to Kumar et al., (1995) method as stated below:

$$
B T F=\frac{c_{\text {biota }}}{C_{\text {soil }}}
$$

where $\mathrm{C}_{\text {biota }}$ is the total concentration of metal in plant, $\mathrm{C}_{\text {soil }}$ is the total concentration of metal in the soil. Bio Translocation Factor (BTLF) of metal in plant samples were evaluated with the formula as in equation (2) (Barman et al., 2000; Gupta et al., 2008).

$$
B T L F=\frac{\text { Concentration of metal in shoot }}{\text { Concentration of metal in root }}
$$

\section{Results}

\subsection{Bio transfer factor (BTF) of Cr in R. racemosa}

The results of wet season mean bio transfer factor (BTF) of $\mathrm{Cr}$ in $R$ racemose indicated the trend which showed that station $1>$ station $2>$ station $4>$ station 3 . The mean BTF for the four stations studied indicated $0.36 \mathrm{mg} / \mathrm{kg}$ of $\mathrm{Cr}$ concentration. Statistical analysis showed significant differences between the stations at $\mathrm{p}=0.05$. The result of least significant difference (LSD) for the above results further signified statistical differences between stations 1 and 2, 1 and 3,1 and 4, 2 and 3, and between stations 2 and 4 at p = 0.05 respectively (Fig. 1). At dry season, the mean BTF of $\mathrm{Cr}$ similarly showed a trend of station $1>$ station $2>$ station $4>$ station 3 levels. The result further showed the mean $\mathrm{BTF}$ of $\mathrm{Cr}$ concentration in $R$. racemosa for the four stations studies as 0.36 
$\mathrm{mg} / \mathrm{kg}$. These results were statistically significant at $\mathrm{p}=0.05$. Furthermore, the LSD analysis indicated statistical differences between stations 1 and 2, 1 and 3,1 and 4, and between stations 2 and 3 at $p=0.05$ respectively (Figure 1).

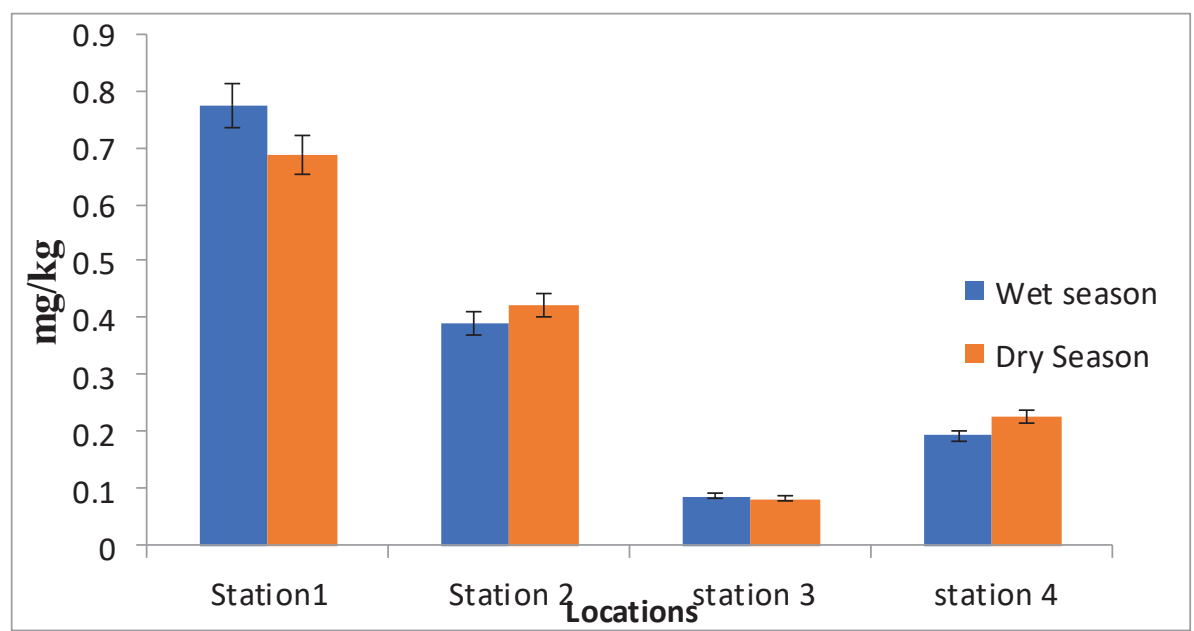

Figure. 1: Wet and dry season bio transfer factor of Chromium in Rhizophora racemosa soil and plant tissues.

\subsection{Bio Translocation factor (BTLF) of Cr in R. racemosa}

The result of wet season mean BTLF of $\mathrm{Cr}$ in the root and shoot tissues of $R$. racemosa presents the trend of station $4>$ station $3>$ station $2>$ station 1 in concentration. These results further indicated the mean concentration of BTLF of the four stations studied $0.51 \mathrm{mg} / \mathrm{kg}$. However, the above results were not statistically different based on stations at $\mathrm{p}=0.05$ (Figure 2). The dry season result of mean BTLF of $\mathrm{Cr}$ in shoot tissues of $R$. racemosa revealed the trend of station $4>$ station $3>$ station $1>$ station 2 in concentration, with mean BTLF of the four stations as $0.41 \mathrm{mg} / \mathrm{kg}$. These results were significantly different in BTLF at $\mathrm{p}=0.05$. Furthermore, the result showed differences in BTLF shoot tissues between stations 1 and 4, 2 and 3, and between station 2 and 4 at $p=$ 0.05 respectively (Figure 2).

Figure 2: Wet and dry season bio translocation factor of $\mathrm{Cr}$ in shoots of $R$. racemosa

\subsection{Bio transfer factor (BTF) of Ni in R. racemosa}

The results obtained at wet season displayed the mean BTF of Ni in $R$. racemose with a trend that showed station $4>$ station $3>$ station $1>$ station 2 in concentrations. The result also revealed the mean BTF of Ni in the four stations studied as $0.86 \mathrm{mg} / \mathrm{kg}$. The above results were statistically significantly different at $\mathrm{p}=0.05$. The LSD result only indicated statistical differences between stations 1 and 2,2 and 3,1 and 4, and between stations 2 and 4 at $p=0.05$ respectively (Figure 3 ). The dry season results unveiled a mean BTF trend of station $3>$ station $1>$ station $4>$ station 2 in $\mathrm{Ni}$ concentrations, while the four stations studied displayed a mean concentration $\mathrm{Ni}$ $\mathrm{BTF}$ as $0.55 \mathrm{mg} / \mathrm{kg}$. These results were significantly different at $\mathrm{p}=0.05$. The result further showed statistical differences in Ni BTF between stations 1 and 2, 2 and 3, 1and 4, 2 and 4, and between stations 3 and 4 at p= 0.05 respectively (Figure 3 ).

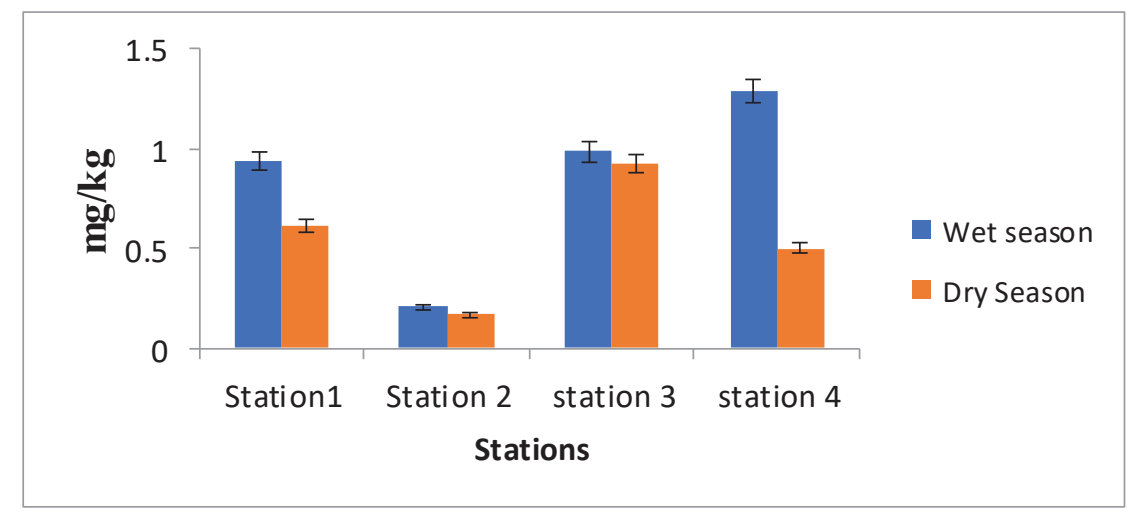

Figure 3: Wet and dry season bio transfer factor of Ni in Rhizophora racemosa soil and plant tissues. 
3.4 Bio translocation factor (BTLF) of Ni in R. racemosa

The The wet season result of mean BTLF of $\mathrm{Ni}$ in root and shoot tissues of $R$. racemosa presented a trend showing station $4>$ station $2>$ station $3>$ station 1 in concentration. The result also indicated the mean BTLF of the four stations studied as $1.47 \mathrm{mg} / \mathrm{kg}$. The result further displayed no statistical differences between BTLF of $\mathrm{Ni}$ in $R$. racemosa based on stations at $\mathrm{p}=0.05$ (Figure 4). The dry season result of mean BTLF of Ni in root and shoot tissues of $R$. racemosa showed the trend of station $4>$ station $3>$ station $2>$ station 1 in concentration. The four stations studied unveiled a mean BTLF of $0.65 \mathrm{mg} / \mathrm{kg}$. These results were not statistically significant at $\mathrm{p}=$ 0.05 (Figure 4).

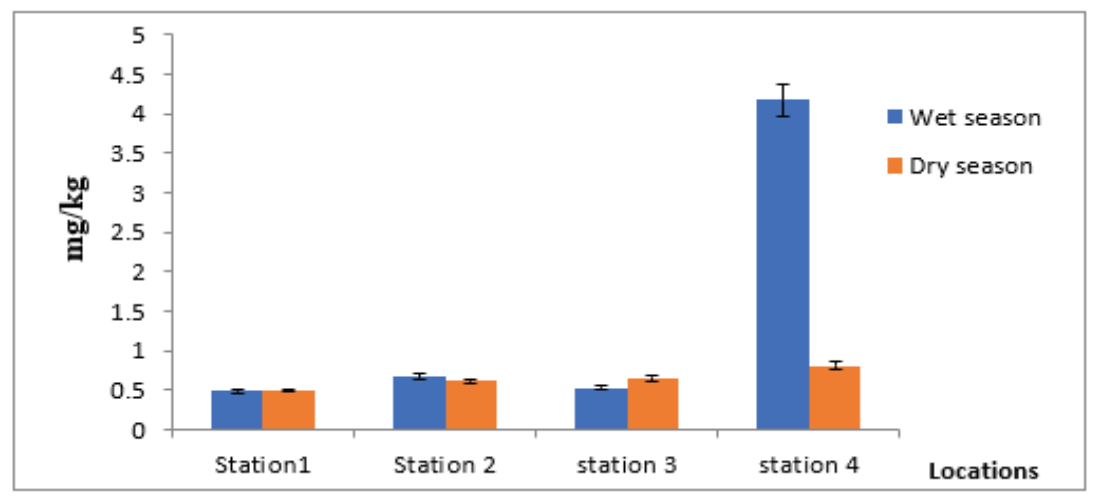

Figure 4: Wet and dry season Bio translocation factor of Nickel in R. racemose root and shoot tissues

\subsection{Bio transfer factor (BTF) of Cd in R. racemosa}

The results of wet season mean bio transfer factor of $\mathrm{Cd}$ in $R$ racemosa revealed a trend showing station $3>$ station $1>$ station $4>$ station 2 in concentration. The result further showed the bio transfer factor of the four study stations as 2.86. The above results were not significantly different based on stations at $\mathrm{p}=0.05$ (Figure 5). The result dry season result unveiled a trend of mean bio transfer factor concentration of station $3>$ station $4>$ station $1>$ station 2 , with a mean BTF of the four study stations as $1.24 \mathrm{mg} / \mathrm{kg}$. These results were statistically significantly different based on stations at $\mathrm{p}=0.05$. The result also showed LSD between stations 1 and 3, 2 and 3,3 and 4 , and stations 2 and 2 at $\mathrm{p}=0.05$ (Figure 5).

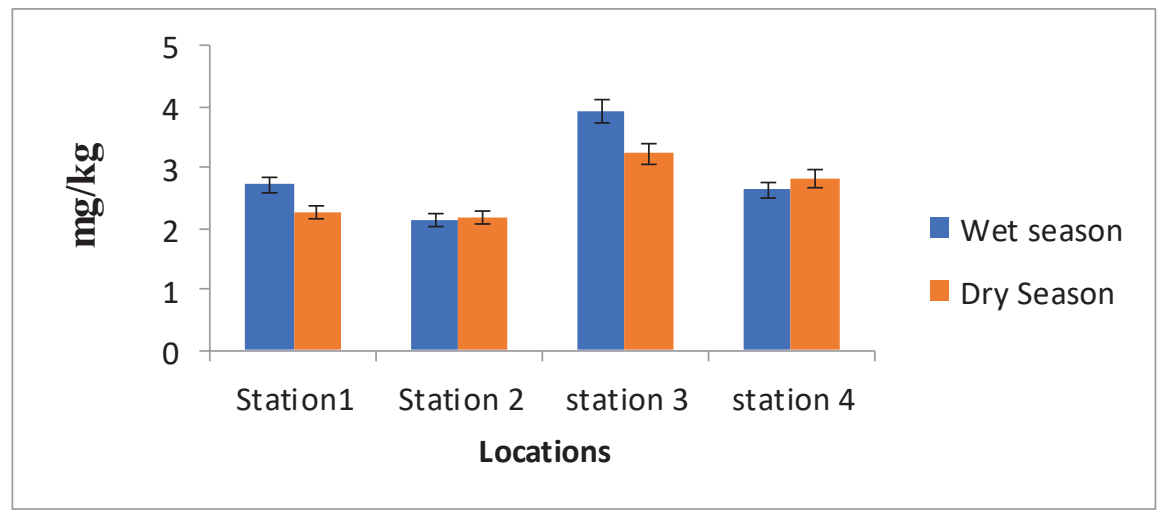

Figure 5: Wet and dry season bio transfer factor of Cd in Rhizophora racemosa soil and plant tissue

\subsection{Bio translocation (BTLF) factor of $C d$ in $R$. racemosa}

The result of wet season BTLF of Cd in R. racemosa root and shoot tissues showed the trend of station $4>$ station $3>$ station $2>$ station 1 in concentration. The four stations studied had a mean BTLF concentration of $1.02 \mathrm{mg} / \mathrm{kg}$. There were no significant differences in BTLF of Cd in $R$. racemosa root and shoot tissues based on stations at $\mathrm{p}=0.05$ (Figure 6). At dry season, the BTLF of Cd in $R$. racemosa root and shoot tissues indicated the trend showing station $3>$ station $4>$ station $1>$ station 2 in concentration, with the mean of the four studied stations as $1.24 \mathrm{mg} / \mathrm{kg}$. These results showed statistical differences in Cd BTLF based on stations at $\mathrm{p}=0.05$. The result further showed differences in Cd BTLF between stations 2 and 3 and between stations 2 and 4 at $\mathrm{p}=$ 0.05 respectively (Figure 6). 


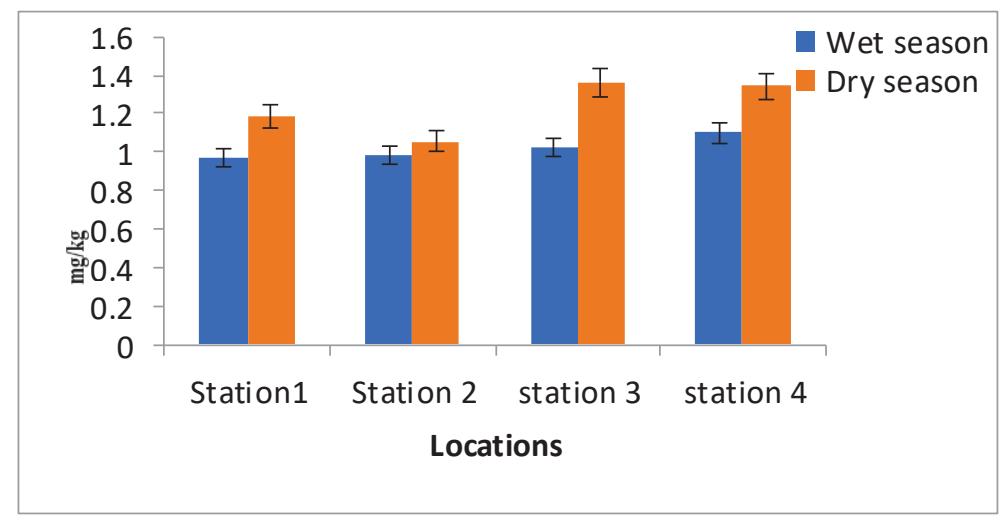

Figure 6: Wet and dry season bio translocation factor of $\mathrm{Cd}$ in $R$. racemose root and shoot tissues

3.7 Bio transfer factor (BTF) of Pb in R. racemosa

The result of wet season evaluation of mean $\mathrm{BTF}$ of $\mathrm{Pb}$ in $R$. racemosa soil and plant tissues showed the trend of station $1>$ station $4>$ station $2>$ station 3 in concentrations. The result further indicated the mean $\mathrm{BTF}$ of $\mathrm{Pb}$ of the four study stations as $1.17 \mathrm{mg} / \mathrm{kg}$. The result however displayed no statistical differences in the mean TF of $\mathrm{Pb}$ based on stations at $\mathrm{p}=0.05$ (Figure 7). At dry season, the mean $\mathrm{BTF}$ of $\mathrm{Pb}$ in $R$. racemosa soil and plant tissues showed the trend of station $2>$ station $4>$ station $1>$ station 3 in concentration, the mean BTF of Pb for the four studied stations as $2.72 \mathrm{mg} / \mathrm{kg}$. These results showed no statistical differences inBTF based on stations at $\mathrm{p}=0.05$ (Figure 7).

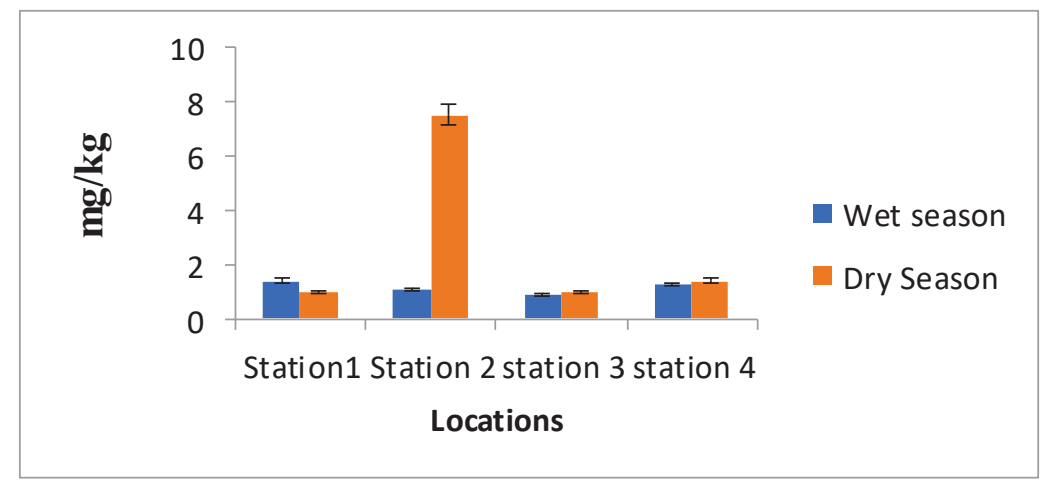

Figure 7: Transfer factor of Lead in Rhizophora racemosa growth soil and plant tissue

\subsection{Bio translocation factor (BTLF) of $\mathrm{Pb}$ in $\mathrm{R}$. racemosa}

The wet season result of $\mathrm{Pb} \mathrm{BTLF}$ in $R$. racemosa root and shoot showed a trend of station $2>$ station $3>$ station $4>$ station 1 in concentration. The result further showed the mean level of Pb BTLF of the four stations studied as $1.48 \mathrm{mg} / \mathrm{kg}$. The results were statistically significant based on stations at $\mathrm{p}=0.05$ (Figure 8 ). The dry season results presented the trend of station $2>$ station $4>$ station $3>$ station 1 in Pb BTLF concentration. The result further showed the mean level of Pb BTLF of the four stations studied as $1.50 \mathrm{mg} / \mathrm{kg}$. These results statistically significant based on stations at $\mathrm{p}=0.05$ (Figure 8 ). 


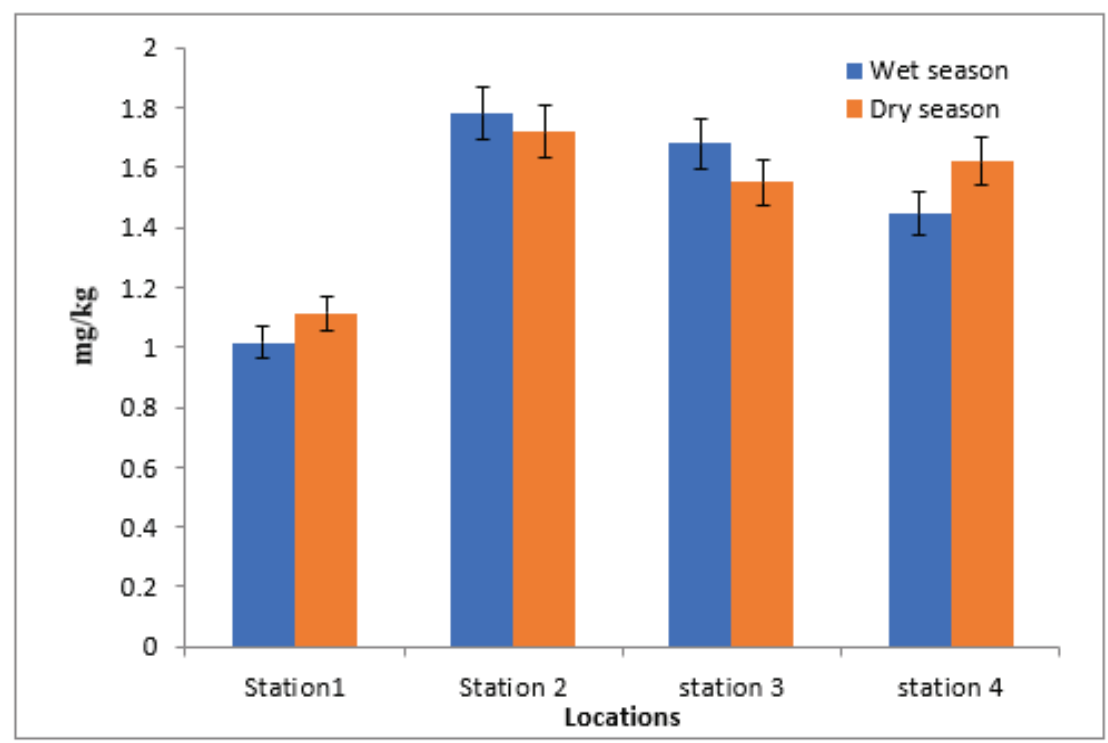

Figure 8: Wet and dry season bio translocation factor of $\mathrm{Pb}$ in $\mathrm{R}$. racemose root and shoot tissues

\subsection{Bio transfer factor (BTF) of Zn in R. racemosa}

The result of wet season evaluation of $\mathrm{Zn} \mathrm{BTF}$ in $R$. racemosa growth soil and plant tissues showed a trend of station $4>$ station $2>$ station $1>$ station 3 in concentration. The result further revealed the $\mathrm{Zn} \mathrm{BTF}$ of the four studied stations as $1.85 \mathrm{mg} / \mathrm{kg}$. The results were not statistically different at $\mathrm{p}=0.05$ (Fig. 9). The dry season result revealed the $\mathrm{Zn} \mathrm{BTF}$ trend of station $4>$ station $2>$ station $1>$ station 3 in concentration. Furthermore, result showed the mean BTF of $\mathrm{Zn}$ at the four studied stations as $1.99 \mathrm{mg} / \mathrm{kg}$. These results were not generally significantly different based on stations at $\mathrm{p}=0.05$. However, the LSD result indicated statistical differences between stations 1 and 2, 2 and 3, and between 3 and 4 at $\mathrm{p}=0.05$ (Figure 9).

\subsection{Bio translocation factor (BTLF) of Zn in R. racemosa}

The results of wet season BTLF of $\mathrm{Zn}$ in $R$. racemosa root and shoot tissues showed the trend of station $2>$ station $3>$ station $4>$ station 1 in mean concentration. The result also showed the mean BTLF of the four studied stations as $0.88 \mathrm{mg} / \mathrm{kg}$. These results showed no statistical differences in BTLF based on stations at $\mathrm{p}=$ 0.05. The LSD result only showed differences between stations 3 and 4 (Figure 10). The dry season results of presented a BTLF trend of station $4>$ station $2>$ station $3>$ station 1 in mean concentration of $\mathrm{Zn}$. The result further showed the mean BTLF of the four studied stations as $0.81 \mathrm{mg} / \mathrm{kg}$. These results were not significant based on stations at $\mathrm{p}=0.05$ (Figure 10).

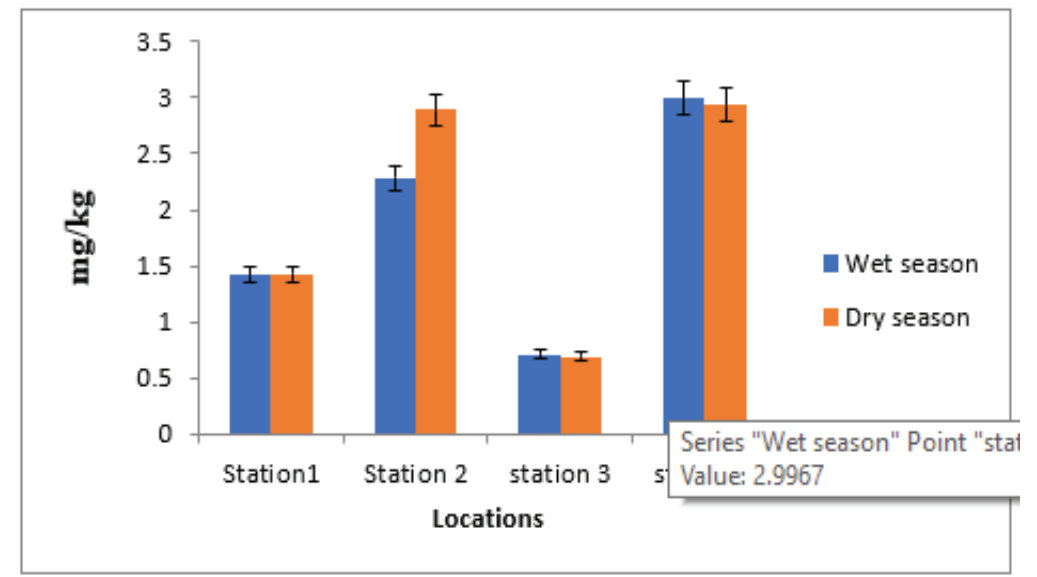

Figure 9: Wet and dry seasonbio transfer factors of $\mathrm{Zn}$ in Rhizophora racemosa soil and plant tissue 


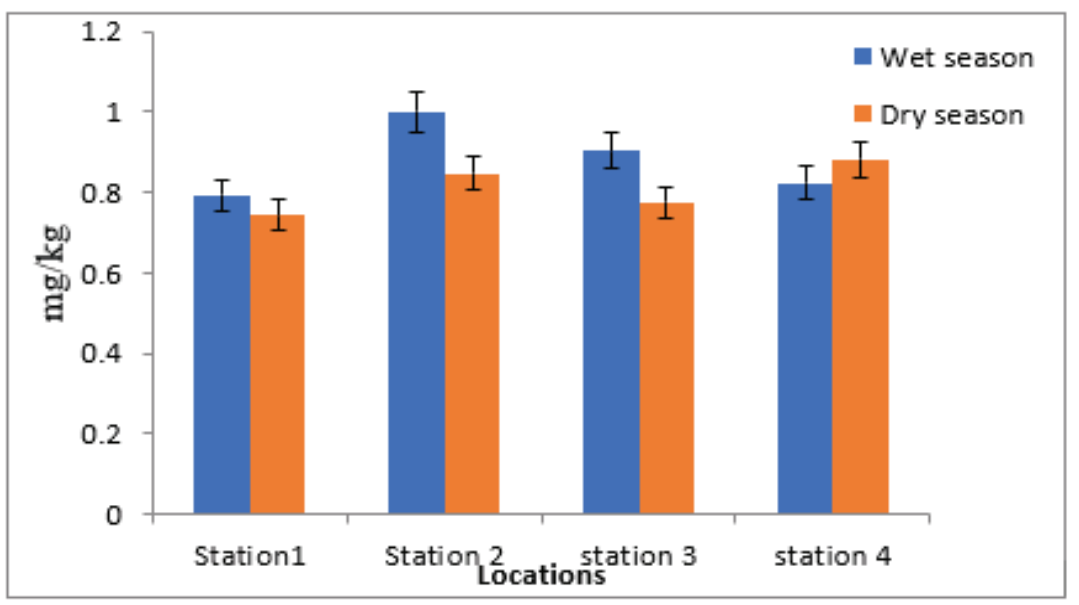

Figure 10:Wet and dry season bio translocation factors of Zinc in $R$. racemose root and shoot tissues

\section{Discussion}

This study on bio transfer and bio translocation factors of heavy metals in the tissues of $R$. racemose displayed different accumulation reactions with respect to the metal species studied.

Findings on $\mathrm{Cr}$ accumulation indicated that $R$. racemos $a$ accumulated more $\mathrm{Cr}$ in their root tissues than their shoot tissues. The observed high concentration of $\mathrm{Cr}$ in the root tissues is attributable to bioavailability and low mobility of $\mathrm{Cr}$ to natural plant extraction process as observed by Komerek et al., (2007). The result of $\mathrm{Cr}$ bio transfer factor (BTF) in R. racemosa was significant at $\mathrm{p}<0.05$, with significant LSD across stations. The result of bio translocation factor (BTLF) signified that higher concentrations of $\mathrm{Cr}$ was transferred into the roots of the plant and these BTLF levels were significant at $\mathrm{p}=0.05$, with variability in LSD across the study stations. The bio transfer and translocation factors were $<1.0$, an indication that $\mathrm{Cr}$ was mainly concentrated in the root tissues. The above findings corroborate the report of McGrath et al. (2001) who reported that some plants accumulated higher concentrations of heavy metals in their roots than shoot tissues and and consequently referred such plants as non-hyper accumulators. Similarly, Debargha et al. (2013) observed low bioaccumulation factor of $\mathrm{Zn}, \mathrm{Cu}, \mathrm{Pb}$ and $\mathrm{Cr}$ in Avicennia officinalis with BTLF $<1$, an observation which they interpreted as an indication that $A$. officinalis took up and translocated the referenced metals below the concentration exhibited by hyper accumulator plants. Also, Baker et al. (1994) described the concentration ratio of 1.0 as an indication that such metal was mainly accumulated in the shoots. It can thus be inferred from the findings of this study that $R$. racemosa is a non-hyper accumulator of $\mathrm{Cr}$.

The results of Ni accumulation displayed that $R$. racemosa accumulated more concentrations of $\mathrm{Ni}$ in their roots than shoot tissues. These results were significant, with LSD across the study stations at $p<0.05$. The above finding contradicts the report of Pahalawattaarachchi et al. (2011) who observed that $\mathrm{Ni}$ were mostly concentrated in the shoot tissues than root tissues of Rhizophora macronata. However, the finding of this study was consistent with those of Komerek et al. (2007), who reported high level of $\mathrm{Cr}$ in roots than in shoot tissues. Earlier studies had pointed to the fact that hyper accumulator plants were not only tolerant to high concentrations of pollutants but also exhibited bioconcentration and translocation factors that are greater than one (Ma et al., 2001). Finding of this study has shown that $R$. racemose dissipated a $\mathrm{BTF}<1$, an observation that classify the plant as a non-hyper accumulator of $\mathrm{Ni}$.

The study on $\mathrm{Cd}$ accumulation showed that $R$. racemose accumulated more concentrations of $\mathrm{Cd}$ in their shoot tissues than root tissues. The results were significant across stations at $p<0.05$. The above finding is in tandem with an earlier observation by Pahalawattaarachchi et al. (2011) who reported high concentrations of Cd, $\mathrm{Zn}, \mathrm{Ni}$ and $\mathrm{Pb}$ in the shoots than roots of Rhizophora macronata. In their report, they stated low uptake capacity of the referenced metals studied. Similarly, Nirmal et al. (2011) reported high concentration of Cd in the leaves of Avicennia marina. The evaluated bio transfer and bio translocation factors of $\mathrm{Cd}$ in this study showed concentration $>1.0$. The findings in this study corroborate an earlier report by Ma et al. (2001) who observed that tolerant plants to high concentrations of pollutants equally exhibit bioconcentration and translocation factors $>1$. The finding of this study has indicated that $R$. racemose exhibited the characteristics of a hyper accumulator plant and consequently be classified as a hyper accumulator of $\mathrm{Cd}$.

The study on $\mathrm{Pb}$ accumulation in the tissues of $R$. racemosa and showed that $R$. racemosa accumulated high levels of $\mathrm{Pb}$ in their shorts than root tissues. Although, the concentrations were not significantly different across stations. Various reports had indicated the accumulation of $\mathrm{Pb}$ in the shoot tissues of mangrove species (Pahalawattaarachchi et al., 2011; Nirmal et al., 2011; Qiu et al., 2011). 
The bio transfer and bio translocation factors of $\mathrm{Pb}$ in $R$. racemose shoot tissues were $>1$, which is an attribute of hyper accumulator plants. It is there inferred that $R$. racemose is a hyper accumulator of $\mathrm{Pb}$ in shoot tissues.

The results on the evaluation of zinc $(\mathrm{Zn})$ accumulation in the tissues that $R$. racemose indicated an accumulation of substantial concentrations of $\mathrm{Zn}$ in root tissues, with a bio transfer factor $>1.0$. However, this result was not significantly different across stations at $\mathrm{p}<0.05$. Similarly, the bio translocation factors were not significant. Root tissues had been shown to accumulate higher concentration of most metals than shoot tissues (Pahalawattaarachchi et al., 2009; Nirmal Kumar et al., 2013 and Almasheer et al., 2014). The high levels of accumulation of metals in root tissues had earlier been attributed to low mobility and bioavailability of the metals to natural process of plant uptake (Komerek et al., 2007). Consequent to the finding of this study, $R$. racemosa can be classified as a non-hyper accumulator of $\mathrm{Zn}$ in root tissues.

\section{Conclusion}

The phyto-extraction potential of selected metals by $R$. racemose was evaluated in this study using bio transfer factor and bio translocation factor analysis. Findings of the study have shown that the study plant exhibited varying responses to the accumulation of the metals studied. The study unveiled that besides other attributes such as serving as a spooning habitat for various endemic fisheries and as well as home to many faunas in the Niger Delta mangrove forest, $R$. racemose can be used for phytoremediation of the metals to which it shows high affinity and potentials for accumulation. The study indicated and classified $R$. racemose as a hyper accumulator of $\mathrm{Pb}$ and $\mathrm{Cd}$ in their shoot tissues, and a non-hyper accumulator of $\mathrm{Cr}$, $\mathrm{Ni}$ and $\mathrm{Zn}$ in their root tissues.

\section{References}

Adeola, F. O (2000).Endangered community, enduring people: Toxiccontamination, health, and adoptive responses in a local context. Environ. Behav. 32:209-249.

Almahasheer, HB; Al-Taisan, WA; Mohamad, MK (2014). Metals accumulation in Grey Mangrove (Avicennia marina (Forsk) Vierh) inhabiting Tarut Bay, Eastern Saudi Arabia. J Agricul Sci, 6(1): 137- 149.

Amnesty International (2009). Nigeria: Petrolium, pollution and poverty in the Niger Delta Nigeria: Petrolium, pollution, and poverty in Niger Delta. Amnesty International Publication, London, UK.

Baker, A. J. M., Reeves, R. D. and Hajar, A. S. M. (1994). Heavy metal accumulation and tolerance in British Population of the metallophyte Thlaspi cacrulenscens. J. \& C. Presl (Brassicaceae). New Phytologist, 127:61-68.

Barman, SC; Sahu, RK; Bhargava, SK; Chatterjee, C (2000). Distribution of heavy metals in wheat mustard and weed grains irrigated with industrial effluents. Bullet Environ Contam and Toxicol, 64: 489-496.

Baryla, A; Carrier, P; Frank, F; Coulomb, C; Sahut, and Havaux, M (2001). Leaf chlorosis in oil seed rape plant (Brassica napus) grown on cadmium-polluted soil: causes and consequences for photosynthesis and growth. Planta, 212: 696-709.

Carnie, T (2004). Toxic tide is taking its toll on Africa. The Mercury Newspaper (South Africa), 24 February p 2.

Debargha, C; Subhajit, B; Jayjit, M; Santra, SC (2013). Heavy metal pollution and phytoremediation potential of Avicinnia officinalis L. in the southern Coast of Hoogly estuarine system. Int J Environ Sci, 3(16):22912303.

Erakhrumen, AA (2014). Potential of Rhizophora racemosa for Bio-indication and Dendro remediation of heavy metal contamination in a mangrove forest, Ondo State Nigeria. Nig J Agric, Food Environ, 10(4): 1-5.

Erakhrumen, AA (2007). Phytoremediation: An environmentally sound technology for pollution prevention, control and remediation in developing countries. Educational Research and Review, 2(7):151-156

Ghosh, M. and Singh, S. P. (2005). A review of phytoremediation of heavy metals and utilization of its byproducts. Applied Ecology and Environmental Research, 3(1): 1-18

Gupta, S; Nayek, S; Saha, RN; Satpati, S (2008). Assessment of heavy metal accumulation in macrophyte, agricultural soil and crop plants adjacent to discharge zone of sponge iron factory. Environ Geol, 55:731739 .

Komarek, M; Tlustos, P; Szakova, J; Chrastny, V; Balik, J (2007). The role of Fe and Mn oxides during EDTAenhanced phytoextraction of heavy metals. Plant, Soil Environ, 53(5): 216-224.

Ma, LQ; Komar, KM; Tu, C; Zhang, W; Cai, Y; Kennelley, ED (2001). A fern that accumulates arsenic. Nature, 409: 579.

Marchand, C; Lallier Verges, E; Baltzer, F; Alberic, P; Cossa, D and Baillif, P (2006). Heavy metals distribution in mangraove sediments along the mobile coastline of French Guiana. Marine Chemistry, 98(1);1-17

McGrath, SP; Zhao, FJ; Lombi, E (2001). Plant and Rhizosphere processes involved in phytoremediation of metal contaminated soil. Plant Soil, 232: 207-214.

Neff, J. M., Johnson, S., Frost, T. K., Utvik, T. I. R. and Durell, G. S. (2006). Oil well produced water discharges to the North Sea, part 11 comparison of deployed Mussels (Mytilus edilus) and the Dream Model to predict 
ecological risk. Marine Environmental Research,

62: 224-246.

Nirmal Kumar, IJ; Sajish, PR; Nirmal Kumar, R; Basil, G; Shailendra, V (2011). An assessment of the accumulation potential of $\mathrm{Pb}, \mathrm{Zn}$ and $\mathrm{Cd}$ by Avicennia marina (Forssk Vierh) In: Vamleshwar mangroves, Gujarat, India. Notulae Sci Biologicae, 3(1): 36-40.

Pahalawattaarachchi, V; Purushothaman, CS; Vennila, A (2009). Metal phytoremediation potential of Rhizophora mucronata (Lam). Ind J Mar Sci, 38(2): 178-183.

Stoltz, E and Greger, M (2002). Accumulation properties of As, Cd, Cu, Pb and $\mathrm{Zn}$ by four wetland plant species growing on submerged mine tailings. Environ. Exp. Bot. 47: 271- 280.

Sulton, J. C and Shun, L (1996). The scientific characterization of the Delware Estuary. The Delware Estuary programme (DRBC project no. 321; HA file no. 93.21) 200pp and Appendices.

Tordoff, M. M; Baker, A. J. M and Willis, A. J (2000). Current approaches to the revegetation and reclamation of metalliferous mine wastes. Chemosphere, 41:219-228.

Qiu, Y; Lin, D; Liu, J; Zeng, EY (2011). Bioaccumulation of trace metals in farmed fish from South China and potential risk assessment. Ecotoxicol Environ Safety, 74: 284-293. 